\title{
Decreased Serum Insulin-like Growth Factor I during Puberty in Children with Insulin Dependent Diabetes Mellitus (IDDM)
}

\author{
Erik Kreyberg Normann, ${ }^{1}$ Uwe Evald, ${ }^{2}$ Knut Dahl-Jørgensen, ${ }^{1}$ Stig Larsen, ${ }^{3}$ \\ Nils Norman ${ }^{4}$ and Torsten Tuvemo ${ }^{2}$ \\ 'Department of Pediatrics, Aker University Hospital, Oslo, Norway, \\ ${ }^{2}$ Department of Pediatrics, Uppsala University Children's Hospital. \\ Uppsala, Sweden, ${ }^{3}$ MedStat, Strommen, Norway and ${ }^{4}$ Hormone laboratory, \\ Aker University Hospital, Oslo, Norway
}

\begin{abstract}
Previous reports concerning insulin-like growth factor-I (IGF-I) in diabetics are conflicting. This study describes IGF-I in children with insulin-dependent diabetes mellitus (IDDM) and healthy controls in relation to pubertal development. Sixty-six children participated ( 34 girls and 32 boys) of which 33 had IDDM. The mean age in the study population was 14.3 years, (range 7.1 to 19.7).

Serum IGF-I was significantly decreased in diabetics. Diabetic girls had a mean IGF-I of $28.3(14.4 ;=\mathrm{SD}) \mathrm{nmol} / \mathrm{l}$ compared with $42.8(15.0) \mathrm{nmol} / \mathrm{l}$ in controls. In diabetic boys the result was $30.0(16.0) \mathrm{nmol} / \mathrm{l}$ compared with $44.1(23.4)$ in controls.

Growth hormone was measured in only one fasting morning serum sample from each individual. There was no difference between girls, but diabetic boys had higher mean serum concentration of growth hormone than controls $(3.5$ (4.8) vs. $1.8(1.5) \mu \mathrm{g} / 1$ respectively). Diabetic girls had delayed menarche, corresponding to a slightly delayed bone maturation.
\end{abstract}

\section{INTRODUCTION}

Diabetics are in some reports found to have lower serum concentrations of insulin-like growth factor I (IGF-I) than controls (4). After the first 6-9 months postnatally serum IGF1 is mainly regulated by growth hormone and nutritional status. Normally IGF-I increases two-three-fold during puberty and declines with aging $(3,5)$. Several studies have been published about serum levels of IGF-I in diabetics but few studies were performed in children or adolescents. The results are conflicting. In a review of the literature in 1990 some studies were reported showing increased values in diabetics, some normal while some showed decreased concentrations of IGF-I in serum compared with controls (4). During puberty most diabetics have impaired metabolic control. Children with insulindependent diabetes mellitus (IDDM) have been reported to have delayed puberty compared 
with controls and in some reports they were shorter. The normal growth spurt was retarded $(1,13,14)$ and IGF-I concentrations decreased compared with healthy controls $(2,6)$.

The reports about the relation between the level of IGF-I and microangiopathy have been contradictory. Nardelli did not find any correlation between retinopathy and levels of IGFI, while Merimee found the IGF-I level significantly elevated in patients with rapid proliferative retinopathy compared with patients with less severe retinopathy $(8,9)$.

Because of these contradictory reports, concerning both the IGF-I levels in diabetics and the correlation to angiopathy, we have investigated the pubertal development and the hormonal changes, including IGF-I, in children with IDDM and a control group of healthy children.

\section{PATIENTS AND METHODS}

\section{Patients}

Thirty-three insulin-dependent diabetic patients were included, 17 girls and 16 boys. As control they all brought a healthy classmate of the same sex and age. The groups were matched for chronological age, bone age, height, weight and body mass index (table 1).

\begin{tabular}{|c|c|c|c|c|c|c|c|}
\hline & $\mathbf{N}$ & $\begin{array}{c}\text { Age } \\
\text { years }\end{array}$ & $\begin{array}{c}\text { Bone age } \\
\text { years }\end{array}$ & $\begin{array}{l}\text { Height } \\
\text { meter }\end{array}$ & $\begin{array}{c}\text { Weight } \\
\text { kg }\end{array}$ & BMI & $\begin{array}{c}\text { Menarche } \\
\text { years }\end{array}$ \\
\hline \multicolumn{8}{|l|}{ Girls } \\
\hline Diabetes & 17 & $14.2(3.0)$ & $13.6(3.3)$ & $1.54(0.13)$ & $52.0(18.0)$ & $21.3(4.7)$ & $13.7(1.4)$ \\
\hline Control & 17 & $14.3(3.1)$ & $14.0(3.2)$ & $1.59(0.12)$ & $55.2(18.0)$ & $21.2(4.8)$ & $13.2(1.1)$ \\
\hline \multicolumn{8}{|l|}{ Boys } \\
\hline Diabetes & 16 & $14.3(2.4)$ & $13.6(2.6)$ & $1.64(0.15)$ & $53.0(16.1)$ & $19.1(2.7)$ & \\
\hline Control & 16 & $14.6(2.5)$ & $14.2(3.1)$ & $1.64(0.16)$ & $51.8(14.5)$ & $18.7(2.0)$ & \\
\hline
\end{tabular}

Table 1. Anthropometric data of boys and girls with and without IDDM (=SD).

Because of the relatively few patients in each pubertal group, the total population was divided into only four main groups. These were two female groups based on breast development $(B<3 ; B \geq 3)$ (according to Tanner's staging (1-5)), and two male groups based on the testicular volume $(T<15 \mathrm{ml} ; \mathrm{T} \geq 15 \mathrm{ml})(12,15)$. 
The mean diabetes duration was 8.0 (range 0.9-15.0) years in girls and 7.0 (1.0-16.5) years in boys. Most diabetics were patients at the outpatient clinic of the Department of Pediatrics, Aker University Hospital, while some came from suburban hospitals of Oslo. The diabetics were all treated with human insulin. Some used two or three injections daily with conventional syringe while others had a multiinjection regimen with insulin-pen. The mean daily insulin dose was $46.4 \mathrm{IU}$ in girls and $42.6 \mathrm{IU}$ in boys (n.s.) $(0.9(0.4-2.2)$ and 0.8 (0.3-1.3) IU/kg body weight respectively; n.s.). There was no difference in systolic or diastolic blood pressure between the diabetic girls and boys $(115 / 73$ and $115 / 69 \mathrm{mmHg}$ respectively) compared with the controls (116/71 and $112 / 67 \mathrm{mmHg}$ respectively). The patients and their parents gave written consent. The study protocol was approved by the local Ethics committee.

\section{Methods}

Both the diabetic patients and controls met fasting at the outpatient clinic at $8.00 \mathrm{a} . \mathrm{m}$. The blood-samples were taken before breakfast and the morning dose of insulin. They were all examined and grouped according to the pubertal developmental staging of Tanner (12). Axillary and pubic hair, breast development, time of menarche and the menstrual cycle were recorded. Penile development and testicular volume (by Prader ${ }^{\mathrm{TM}}$ orchidometer) were measured in boys (15). Standing height was measured with a Holtain ${ }^{\mathrm{TM}}$ stadiometer. Body mass index (BMI) was calculated from the standing height and body weight. To reduce variation the standing height and blood pressure were measured by the same technician. Bone age was estimated according to Greulich-Pyle (10). To reduce variation the bone age was determined by only one experienced radiologist.

HbAlc was measured by HPLC (Diamat ${ }^{\mathrm{TM}}$, normal $<6.1 \%, \mathrm{cv}<3 \%$ ). Insulin-like growth factor I (IGF-I) was measured with a RIA-kit (Immuno NuclearTM). No separation from binding proteins was made. Growth hormone $(\mathrm{GH})$, testosterone, estradiol, follicle stimulating hormone (FSH), luteinizing hormone (LH), dehydroepiandrosterone (DHEA), androstenedione, cortisol and thyroxine were measured by standard RIA-methods.

\section{Statistical methods}

All results were expressed as mean values with standard deviation in brackets. Linear regression analysis was used to analyse the correspondence between IGF-I and pubertal stage in the different groups (7).

All tests used in this analysis were carried out two-tailed and the differences considered significant if the p-values were less than or equal to $5 \%$. The groups were compared by using two-way layout analysis of variance. 


\begin{tabular}{|l|l|l|l|}
\hline & N & \multicolumn{1}{|c|}{$\begin{array}{c}\text { Blood } \\
\text { glucose } \\
\mathbf{m m o l} / \mathrm{l}\end{array}$} & $\begin{array}{c}\mathbf{H b A}_{1} \mathbf{c} \\
\%\end{array}$ \\
\hline Girls & & & \\
\hline Diabetes & 17 & $11.7(5.9)$ & $9.3(1.5)$ \\
\hline Control & 17 & $4.5(0.3)$ & $5.1(0.6)$ \\
\hline Boys & & & \\
\hline Diabetes & 16 & $8.3(4.5)$ & $9.3(1.9)$ \\
\hline Control & 16 & $4.6(0.4)$ & $5.1(0.6)$ \\
\hline
\end{tabular}

Table 2. Blood glucose and $\mathrm{HbA}_{1} \mathrm{c}$ in children with IDDM and controls (=SD).

\section{RESULTS}

Fasting blood glucose and $\mathrm{HbAlc}$ values are given in table 2 . The mean age of menarche was delayed by 0.5 years in diabetic girls. The hormone data are given in tables 3 and 4 . In girls the mean concentration of serum IGF-I increased from $19.2(5.4) \mathrm{nmol} / \mathrm{l}$ in the youngest pubertal group $(B<3)$ to $33.3(15.5) \mathrm{nmol} / 1$ in the oldest $(B \geq 3)$. The pubertal increase of IGF-I in diabetic girls started later than in controls. Control girls had higher values than diabetic girls in early puberty. In early pubertal control boys IGF-1 concentrations were higher than in boys with diabetes. In boys the difference between the mean values in late puberty was not as large as in early puberty (41.3 (13.4) vs. 53.5 (16.0) $\mathrm{nmol} / \mathrm{l}$ and $21.1(12.1)$ vs. 36.7 (26.5) $\mathrm{nmol} / \mathrm{l}$ respectively). These differences were not statistically significant, but grouping all diabetic boys together and comparing them with controls, serum IGF-I concentration was significantly lower $(30.0$ (16.0) vs. 44.1 (23.4) $\mathrm{nmol} / \mathrm{l} ; \mathrm{p}<0.05)$. There was no correlation between IGF-I and metabolic control measured by HbAlc.

\section{DISCUSSION}

There are several studies reporting that the serum IGF-I concentration is decreased in diabetic patients, while some claim the opposite (4). In our study, both diabetic girls and 


\begin{tabular}{|c|c|c|c|c|c|}
\hline & & \multicolumn{2}{|c|}{$\begin{array}{l}\text { IGF-I } \\
\mathrm{nmol} / \mathrm{I}\end{array}$} & \multicolumn{2}{|c|}{$\begin{array}{r}\text { GH } \\
\mu \mathrm{g} / \mathrm{I}\end{array}$} \\
\hline & $\mathbf{N}$ & Diabetes & Controls & Diabetes & Controls \\
\hline All & 33 & $29.1(15.0)^{* * *}$ & $43.4(19.3)$ & $3.9(4.3)$ & $3.1(2.9)$ \\
\hline Girls & 17 & $28.3(14.4)^{*}$ & $42.8(15.0)$ & $4.3(4.0)$ & $4.3(3.4)$ \\
\hline $\mathbf{B}<\mathbf{3}$ & 6 & $19.2(5.4)^{* *}$ & 42.2 (17.9) & $3.1(2.5)$ & $3.5(3.0)$ \\
\hline $\mathbf{B} \geq \mathbf{3}$ & 11 & $33.3(15.5)^{*}$ & $43.1(14.1)$ & $5.0(4.6)$ & $4.7(3.6)$ \\
\hline Boys & 16 & $30.0(16.0)^{*}$ & $44.1(23.4)$ & $3.5(4.8)^{*}$ & $1.8(1.5)$ \\
\hline $\mathrm{T}<15$ & 9 & $21.1(12.1)$ & $36.7(26.5)$ & $1.8(1.1)$ & $2.3(1.8)$ \\
\hline $\mathbf{T} \geq \mathbf{1 5}$ & 7 & $41.3(13.4)$ & $53.5(16.0)$ & $5.7(6.8)^{* *}$ & $1.1(0.3)$ \\
\hline
\end{tabular}

Table 3. Serum IGF-I and growth hormone (GH) in boys and girls, with and without IDDM, at different pubertal stages (=SD).

boys had lower serum IGF-I than controls, also when divided into groups of pubertal development. This is identical to what Nardelli reported in 1989 , who found $0.89 \mathrm{U} / \mathrm{ml}$ of IGF-I in controls compared with $0.62 \mathrm{U} / \mathrm{ml}$ in diabetics $(p<0.01)(9)$. Salardi and coworkers reported in 1986 that serum IGF-I was lower in diabetic prepubertal groups compared with controls. IGF-I was not significantly reduced in pubertal groups (11). They also found increased nocturnal secretion of growth hormone in diabetics suggesting a block in production of IGF-I. In our study we had too few prepubertal children, compared with pubertal, to make any statistical analysis meaningful. By grouping them into one group with pubertal development less than Tanner stage 3 and one with stage 3 or more, we also found that the youngest diabetics as well as the more mature ones had lower IGFI levels than controls. The secretion of GH is normally pulsatile with the highest values 
during the night. Growth hormone was measured as a single test, random morning fasting GH concentration. This reduces the importance of the result. Growth hormone was significantly increased only in our diabetic boys.

\begin{tabular}{|c|c|c|c|c|c|c|c|c|c|}
\hline & $\mathbf{N}$ & $\begin{array}{c}\text { Testo- } \\
\text { sterone } \\
\text { nmol/ }\end{array}$ & $\begin{array}{c}\text { Estradiol } \\
\mathrm{nmol} /\end{array}$ & $\mathrm{IU} /$ & $\begin{array}{l}\text { LH } \\
\text { IU/I }\end{array}$ & $\begin{array}{l}\text { DHEA } \\
\text { pmol/ }\end{array}$ & $\begin{array}{c}\text { Andro- } \\
\text { stenedione } \\
\text { nmol/ }\end{array}$ & $\begin{array}{l}\text { Cortisol } \\
\text { nmol/ }\end{array}$ & $\begin{array}{c}\text { Thyroxine } \\
\text { nmol/l }\end{array}$ \\
\hline Diahetes & 33 & $5.2(7.6)$ & $0.12(0.14)$ & $3.4(2.2)$ & $2.6(2.2)$ & $4.0(2.6)$ & $2.3(1.4)$ & $531(260)$ & $104.3(31.3)$ \\
\hline Girls & 17 & $1.2(0.6)$ & $0.18(0.18)$ & $3.9(2.1)$ & $3.0(2.8)$ & $4.1(2.5)$ & $2.8(1.7)$ & $533(241)$ & 110.7 \\
\hline$B<3$ & 6 & $0.5(0.2)$ & $0.05(0.02)^{*}$ & $2.6(2.1)$ & $0.9(0.7)$ & $2.5(1.2)$ & $1.2(0.4)$ & $537(336)$ & $138.2(34.4)^{*}$ \\
\hline B $\geq 3$ & 11 & $1.6(0.3)$ & $0.25(0.19)$ & $4.6(1.7)$ & $4.2(2.9)$ & $5.0(2.6)$ & $3.8(1.3)$ & $532(192)$ & $95.7(26.5)$ \\
\hline Boys & 16 & $9.5(9.2)$ & $0.07(0.03)$ & $2.9(2.2)$ & $2.1(1.2)$ & $3.9(2.8)$ & $1.8(0.9)$ & $528(287)$ & $97.6(25.8)$ \\
\hline$T<15$ & 9 & $3.4(4.8)$ & $0.06(0.04)$ & $1.9(0.9)$ & $1.5(1.0)$ & $2.4(1.5)$ & $1.2(0.6)$ & $520(184)$ & $107.3(30.0)$ \\
\hline$T \geq 15$ & 7 & $17.3(7.3)$ & $0.08(0.02)$ & $4.2(2.8)^{*}$ & $2.9(1.0)$ & $5.7(3.1)$ & $2.4(0.8)$ & $537(400)$ & $85.0(11.9)$ \\
\hline Controls & 33 & $5.8(8.4)$ & $0.14(0.11)$ & $3.4(2.1)$ & $2.9(2.4)$ & $5.4(4.4)$ & $2.5(1.4)$ & $486(143)$ & $94.1(24.4)$ \\
\hline Girls & 17 & $1.2(0.6)$ & $0.19(0.12)$ & $4.5(2.3)$ & $3.7(2.9)$ & $4.6(3.6)$ & $3.0(1.5)$ & $451(166)$ & $99.4(22.8)$ \\
\hline $\mathrm{B}<3$ & 6 & $0.8(0.5)$ & $0.11(0.06)$ & $4.2(2.3)$ & $1.5(1.1)$ & $3.6(3.0)$ & $2.0(1.3)$ & $419(169)$ & $99.8(16.4)$ \\
\hline$B \geq 3$ & [1] & $1.5(0.5)$ & $0.24(0.12)$ & $4.7(2.4)$ & $1.9(2.9)$ & $5.2(3.8)$ & $3.5(1.3)$ & $469(169)$ & $99.1(26.4)$ \\
\hline Boys & 16 & $10.7(10.1)$ & $0.08(0.04)$ & $2.2(1.0)$ & $2.1(1.4)$ & $6.2(5.1)$ & $2.1(1.3)$ & $524(108)$ & $88.6(25.6)$ \\
\hline$T<15$ & 9 & $5.0(6.4)$ & $0.05(0.02)$ & $2.2(1.2)$ & $1.5(1.2)$ & $3.4(1.2)$ & $1.4(0.8)$ & $500(94)$ & $99.4(26.5)$ \\
\hline$T \geq 15$ & 7 & $18.0(9.5)$ & $0.11(0.04)$ & $2.1(0.5)$ & $2.8(1.4)$ & $9.7(6.1)$ & $2.9(1.5)$ & $555(125)$ & $74.6(17.2)$ \\
\hline
\end{tabular}

Table 4. Fasting morning serum hormone concentrations in boys and girls, at different pubertal stages $(=\mathrm{SD})$ 
There are previous reports of reduced height and delayed pubertal development in diabetic adolescents compared with controls. Most of the diabetic patients reach a normal adult height. They will grow slightly slower but for a longer period because of the delayed pubertal development, thus reaching normal adult stature $(1,2,6,13,14)$. The girls in our study were significantly delayed in menarche although the pubertal staging was the same in both the diabetic and the control group. The delay is associated with a significantly lower mean value of estradiol in the diabetic group compared with controls $(p<0.05)$.

The mechanism behind the reduced serum IGF-1 in our adolescent diabetic patients is not completely clear. The study demonstrates that the reduction of IGF-1 was present also when pubertal stage and age were taken into consideration. The decreased IGF-1 levels were not correlated with poor metabolic control. There is no evidence for intensive exercise in the diabetic children explaining some part of the reduced IGF-1. Diabetes during puberty can thus be considered an IGF-1 deficient state. This deficiency seems to be connected to increased growth hormone concentrations at least in boys, which might be due to lack of negative feed back control. This study was performed before the possibility to measure free IGF-I had appeared, so changes in IGF-binding protein levels can not be excluded. The importance of these findings on diabetes regulation and long term complications have to be further studied.

\section{References.}

1. Beal, C. K.: Body size and growth rate of children with diabetes mellitus. J Pediatr 32:170-9, 1948.

2. Clarson, C., Daneman, D. \& Ehrlich, R. M.: The relationship of metabolic control to growth and pubertal development in children with insulin-dependent diabetes. Diabetes Res 2:237-41, 1985.

3. D'Ercole, A. J.: Somatomedins/insulin-like growth factors. Clinical paediatric endocrinology Oxford: Blackwell scientific publications, 74-95, 1989. (Brooke CGD). 4. Flyvbjerg, A.: Growth factors and diabetic complications. Diabetic Med 7:387-99, 1990. 5. Furlanetto, R. W. \& Cara, J. F.: Somatomedin-C/insulin-like growth factor-I as a modulator of growth during childhood and adolescence. Horm Res 24:177-84, 1986. 6. Hjelt, K., Brændholt, V., Kamper, J. \& Vestermark S.: Growth in children with diabetes mellitus. Dan Med Bull 30:28-33, 1983.

7. Kendall, M. \& Stuart, A.: The advanced theory of statistics. 2nd ed. London: Charles Griffin \&Co. Ltd, 1979.

8. Merimee, T. J., Gardner, D. P., Zapf. J. \& Froesch, E. R.: Effect of glycemic control 
on serum insulin-like growth factors in diabetes mellitus. Diabetes 33:790-3, 1984.

9. Nardelli, G. M., Guastamacchia, E., Di Polo, S., Balice, A., Rosco, M., Santoro, G., Lollino, G. \& Giorgino, R.: Somatomedin -C (Sm-C). Study in diabetic patients with and without retinopathy. Acta Diabetol Lat 26:217-24, 1989.

10. Pyle, S.I., Waterhouse, A. M. \& Greulich, W. W.: Radiographic standard of reference for the growing hand and wrist. T-he press of case. Western: Western Reserve University, 1971.

11. Salardi, S., Cacciari, E., Ballardini, D., Righetti, F., Capelli, M., Cicogani, A., Zucchini, S., Natali, G. \& Tassinari, D.: Relationships between growth factors (Somatomedin-C and growth hormone) and body development, metabolic control, and retinal changes in children and adolecents with IDDM. Diabetes 35:832-6, 1986.

12. Tanner, J. M.: Growth at Adolescence, 2nd ed. Oxford: Blackwell Scientific Publications, 1962.

13. Tattersall, R. B. \& Pyke, D. A.: Growth in diabetic children. Studies in identical twins. Lancet ii:1105-09, 1973.

14. Wise, J.E., Kolb, E.L. \& Sauder, S. E.: Effect of Glycemic Control on Growth Velocity in Children With IDDM. Diabetes Care 15:826-30, 1993.

15. Zachmann, M., Prader, A., Kind, H. P., Haflinger, H. \& Budliger, H. Testicular volume during adolescence. Helvetica Paediatrica Acta, 29:61-72, 1974.

Corresponding address: Erik Kreyberg Normann, Department of Pediatrics, Aker University Hospital, 0514 Oslo 5, Norway. 